\title{
Biosynthesis of zinc oxide nanoparticles using Fumaria parviflora extract and evaluation of their antibacterial and antioxidant activities
}

\author{
Behrooz Dousti *, AMIn Habibi, Fatemeh NABIPOR \\ Khorramabad Branch, Islamic Azad University, Khorramabad, Iran
}

\begin{abstract}
Green synthesis is a biocompatible and stable method of producing zinc oxide nanoparticles ( $\mathrm{ZnONPs}$ ).In the present study, ZnONPs were biosynthesized using Fumaria parviflora extract by the green method, and the antibacterial and antioxidant properties of these NPs were evaluated. The characteristics of the synthesized ZnONPs were determined by ultraviolet-visible spectrophotometry (UV-VIS), X-ray diffraction (XRD), and scanning electron microscopy (SEM). The antioxidant activity of the NPs was tested by the $\alpha$-diphenyl- $\beta$-picrylhydrazyl (DPPH) method. Antibacterial properties of the synthesized ZnONPs were evaluated against Staphylococcus aureus and Escherichia coli by disc diffusion and microdilution methods. The results of UV-VIS spectroscopy revealed an absorption peak at $370 \mathrm{~nm}$. XRD results showed the formation of a hexagonal wurtzite structure, and SEM analyses demonstrated that $\mathrm{ZnONPs}$ had a spherical shape with an average size 42 to $60 \mathrm{~nm}$. Free radical scavenging capacity of $\mathrm{ZnONPs}$ was assessed using the DPPH assay with varying concentrations of $\mathrm{ZnONPs}$, and scavenging activity was observed with $\mathrm{IC}_{50}$ of $30.86 \mu \mathrm{g} / \mathrm{ml}$. In the antibacterial assay, the inhibition zone of the synthesized NPs at $100 \mu \mathrm{g} / \mathrm{ml}$ concentration for $S$. aureus $(24.6 \pm 0.72)$ was greater than that of the antibiotics vancomycin $(23 \pm 0.51)$ and a mikacin $(13 \pm 0.40)$ and was greater for $E$. coli $(13.2 \pm 0.81)$ than that of vancomycin $(12 \pm 0.41)(P \leq 0.05)$. The minimum inhibitory concentration (MIC) and the minimum bactericidal concentration $(\mathrm{MBC})$ values of $\mathrm{ZnONPs}$ for $S$. aureus and $E$. coli were 1.56 and $3.125 \mu \mathrm{g} / \mathrm{ml}$, and 6.25 and $12.5 \mu \mathrm{g} / \mathrm{ml}$, respectively. The biosynthesized $\mathrm{ZnONPs}$ showed strong antibacterial and antioxidant activities.
\end{abstract}

Key words: ZnONPs, Fumaria parviflora, antibacterial, antioxidant, green method

Abbreviations

$\begin{array}{ll}\text { ZnONPs } & -\mathrm{ZnO} \text { nanoparticles } \\ \text { UV-VIS } & \text { - ultraviolet-visible spectroscopy } \\ \text { XRD } & - \text { X-ray diffraction }\end{array}$

$$
\begin{array}{ll}
\text { ZnONPs } & - \text { ZnO nanoparticles } \\
\text { UV-VIS } & - \text { ultraviolet-visible sp } \\
\text { XRD } & - \text { X-ray diffraction }
\end{array}
$$

\section{Introduction}

Nanobiotechnology is one of the new technologies in the field of biological sciences. Nanoparticles (NPs) have molecular size of 1-100 nm. Several methods are used to synthesize NPs, such as physical, chemical, and biological methods. Physical methods include plasma arcing, vapor deposition, spray pyrolysis, plasma and ultrasonic irradiation, lithographic techniques, molecular beam epistaxis, and diffusion flame synthesis of NPs (Kong et al., 2001; Guan and Pedraza, 2008; Shoushtari,

\author{
SEM - scanning electron microscopy \\ MIC - minimum inhibitory concentration \\ $\mathrm{MBC}$ - minimum bactericidal concentration
}

* Corresponding author: Khorramabad Branch, Islamic Azad University, Khorramabad, Iran; e-mail: doostybehrooz@yahoo.com 
ventory of resources that may be used to produce biological NPs, such as plants and plant products (Ahmad et al., 2010), algae (Azizi et al., 2014), fungi (Uzzaman et al., 2017), yeasts (Boroumand Moghaddam et al., 2017), bacteria (Kundu et al., 2014; Vahidi et al., 2019), and viruses (Nam et al., 2006). Various studies have suggested that plants are the best option to synthesize biological NPs (Wang et al., 2009). This might be because vegetal substrates are believed to be more cost-effective, easy to process, and less toxic than microorganisms. The use of plant-based substrates also does not involve exposure-related health risks or safety concerns related to hazardous microorganisms (Andeani et al., 2011; Ramesh et al., 2014). Among the metal oxide NPs, zinc oxide NPs have received great interest because of their vast application in various areas such as optical, magnetic, piezoelectric, and gas sensing (Gunalan et al., 2012; Fakhari et al., 2019). Previous studies have revealed that $\mathrm{ZnONPs}$ have strong pharmacological properties such as anticancer (Selvakumar et al., 2015; Anitha et al., 2018), antimicrobial (Soren et al., 2018; Safawo et al., 2018), antioxidant (Stan et al., 2016; Soren et al., 2018), wound healing, anti-inflammatory, and antidiabetic (El-Gharbawy et al., 2016; Agarwal et al., 2017) properties. Thus, researchers have been investigating low-cost, non-toxic and relatively simple methods to biologically synthesize ZnONPs (Das et al., 2017). Biological synthesis of $\mathrm{ZnONPs}$ using various plant extracts such as Aloe barbadensis miller leaf extract (Sangeetha et al., 2011), Cinnamonum camphora (Huang et al., 2007), Azadirachta indica neem, lemongrass (Dwivedi and Gopal, 2010), and tamarind (Ankamwar et al., 2005) has been reported. Antimicrobial activities of metal oxide powders $(\mathrm{ZnO}, \mathrm{MgO}$, and $\mathrm{CaO})$ against Staphylococcus aureus and Escherichia coli have been quantitatively evaluated inculture media (Ankamwar et al., 2005). ZnONPs were shown to exhibit significant antimicrobial activity against both gram-positive and gramnegative bacteria (Raghupathi et al., 2011; Jiménez et al., 2015; Sharma et al., 2016; Jahanpanahiand and Ali Mohamadi, 2016;Vahidi et al., 2019).

Fumaria parviflora Lam. (Fumariaceae) is an annual herbaceous plant that grows in various parts of the IndoPakistan subcontinent, Iran, Middle East, and South Asia. It is commonly known as fine-leaf fumitory, Indian fumitory, or wax dolls in English (Orhan et al., 2012). The phytochemical analysis of $F$. parviflora extract sho- wed the presence of flavonoids, glycosides, tannins, saponins, steroids, phenols, alkaloids, and anthraquinones (Jameel et al., 2014). Pharmacological studies have shown that $F$. parviflora exhibits hepatoprotective (Alqasoumi et al., 2009), antidiabetic (Fathiazad et al., 2013), anti-inflammatory (Rizvi et al., 2017), antipyretic, analgesic, prokinetic, laxative (Rehman et al., 2012), dermatological, antimicrobial (Jameel et al., 2014), antiparasitic (Al-Shaibani et al., 2009), reproductive, and anticholinesterase activities (Orhan et al., 2004). The present study reports for the first time green synthesis of $Z n O N P s$ by using $F$. parviflora extract and their antibacterial and antioxidant activities.

\section{Materials and methods}

\section{Preparation of plant extract}

In early April 2019, F. parviflora was obtained from agricultural lands of the village of Benkashkeh in Mamulan District, located $50 \mathrm{~km}$ from Khorramabad city, Lorestan province, Iran. The aerial parts of the plant were washed with deionized water, air-dried, and ground into fine pieces.To prepare the extract, $10 \mathrm{~g}$ of aerial part powder was heated in $100 \mathrm{ml}$ of deionized water for $15 \mathrm{~min}$ at $70^{\circ} \mathrm{C}$. The aqueous extract was then filtered using a Whatman No. 1 filter paper and stored at $4{ }^{\circ} \mathrm{C}$ until used (Jamdagni et al., 2016).

\section{Synthesis of ZnONPS}

$\mathrm{ZnONPs}$ were synthesized using zinc acetate dehydrate $\mathrm{Zn}\left(\mathrm{CH}_{3} \mathrm{COO}\right)_{2} \cdot 2 \mathrm{H}_{2} \mathrm{O}$ as described previously (Jamdagni et al., 2018). Briefly, $90 \mathrm{ml}$ of zinc acetate solution $(0.01 \mathrm{M})$ was mixed with $10 \mathrm{ml}$ of plant extract and incubated overnight at room temperature. Finally, the prepared $\mathrm{ZnONPs}$ were separated by centrifugation of the reaction mixture at $4500 \mathrm{rpm}$ for $15 \mathrm{~min}$, followed by washing several times with deionized water and then drying at $80^{\circ} \mathrm{C}$ for $7-8 \mathrm{~h}$ (Gunalan et al., 2012; Salem et al., 2015).

\section{Characterization of NPS}

The synthesized $\mathrm{ZnONPs}$ were analyzed using a UVvisible spectrophotometer (model number: Unico 1250) in the range of 200-700 nm (Jamdagni et al., 2016). $\mathrm{X}$-ray diffraction (XRD) analysis was performed on an X-ray diffractometer (Philips X-Pert PRO) operated at $40 \mathrm{kV}$ and $40 \mathrm{~mA}$ with $\mathrm{Cu} \mathrm{K} \alpha$ radiation (1.54060 $\AA$ ) and 
at the scanning rate of $2^{\circ} / \mathrm{min}$. A sample interval of $0.02^{\circ}$ was used in the $2 \Theta$ range from 20 to $80^{\circ}$ to determine the crystallinity, purity, and size of the NPs (Ambika and Sundrarajan, 2015). The surface morphology of ZnONPs was examined by a scanning electron microscope (SEM) operated at an accelerating voltage at $45 \mathrm{kV}$ (Jamdagni et al., 2016).

\section{Evaluation of the antioxidant activity of ZnONPs with DPPH}

The antioxidant activity of $\mathrm{ZnONPs}$ was evaluated on the basis of inhibition of 2,2-diphenyl-1-picrylhydrazyl (DPPH) free radicals (Bhakya et al., 2016). One milliliter of $\mathrm{ZnONPs}$ at various concentrations $(6.25,12.5,25,50$, and $100 \mu \mathrm{g} / \mathrm{ml}$ ) and ascorbic acid (as a standard) were added to different test tubes. Next, $1 \mathrm{ml}$ of DPPH (1mM) dissolved in methanol was added to each tube and vortexed thoroughly. Lastly, the solution was incubated at room temperature in dark for $30 \mathrm{~min}$. The absorbance at $517 \mathrm{~nm}$ wavelength was read with a spectrophotometer, and the percentage of inhibition was calculated using the following equation:

$$
\% \text { inhibition }=(\mathrm{AC}-\mathrm{AS}) / \mathrm{AC} \times 100
$$

[Azimzadeh, 2009]

where $\mathrm{AC}$ is the absorbance of control and AS is the absorbance of sample. Ascorbic acid was used as the standard solution,while $1 \mathrm{mM} \mathrm{DPPH}$ was used as a control.

\section{Antibacterial assay}

The antibacterial activities of $\mathrm{ZnONPs}$ were assessed by disc diffusion and microdilution methods against Staphylococcus aureus ATCC 25923 and Escherichia coli ATCC 25922. Vancomycin and amikacin were used as positive controls.

\section{Disc diffusion method}

In sterile conditions, $10 \mu \mathrm{l}$ of bacterial suspension (opticaldensity $(\mathrm{OD})=0.1$ at $600 \mathrm{~nm}$ ) was inoculated on Muller Hinton Agar (MHA). Next, $30 \mu 1$ of ZnONPs at different concentrations $(25,50$ and $100 \mu \mathrm{g} / \mathrm{ml})$ were impregnated on discs, and the discs were placed on the inoculated MHA plates and incubated for $24 \mathrm{~h}$ at $37^{\circ} \mathrm{C}$. The diameters of inhibition zones around the discs were measured and compared with the results obtained for control antibiotics (vancomycin and amikacin). All experiments were performed in triplicates.

\section{Determination of $M I C$ and $M B C$}

\section{by using the microdilution method}

The minimum inhibitory concentration (MIC) and the minimum bactericidal concentration (MBC) of the synthesized ZnONPs were determined by the broth microdilution methodin 96-well micro-plates. A volume of $100 \mu \mathrm{l}$ of NPs synthesized at the concentration of $100 \mu \mathrm{g} / \mathrm{ml}$ was placed in the first well of the microtiter plate containing $95 \mu \mathrm{l}$ Mueller Hinton Broth (MHB) medium. Serial dilution was performed by pumping the content of the first well, removing $100 \mu \mathrm{l}$ from it, and then adding it to the second well; the dilution procedure was thus continued to form a series of dilution from 100 to $0.195 \mu \mathrm{g} / \mathrm{ml}$. Then, $5 \mu \mathrm{l}$ of bacterial suspension, equivalent to $0.5 \mathrm{McF}$ arland standard $(\mathrm{OD}=0.1$ at $600 \mathrm{~nm})$, was added to wells in columns1 to 11. Positive controls (MHB broth with bacterial suspension) and negative controls (MHB broth plus the synthesized NPs without bacterial suspension) were similarly processed. The microplates were incubated at $37^{\circ} \mathrm{C}$ for $24 \mathrm{~h}$.The absence of bacterial growth was visually checked to define MIC values (Jamdagni et al., 2016). To determine MBC, $10 \mu \mathrm{l}$ from all wells with no or very little visible bacterial growth was removed and cultured on Mueller Hinton Agar media. The plates were then incubated for $24 \mathrm{~h}$ at $37^{\circ} \mathrm{C}$. The $\mathrm{MBC}$ was defined as the lowest concentration that kills $99.9 \%$ of the initial population. All the experiments were repeated three times (Jahanpanahi and Mohamadi Sani, 2016; Nabipour and Dousti, 2018).

\section{Statistical analysis}

The experiments were performed in triplicate. Data are expressed as mean \pm standard deviation. The data obtained were evaluated by a variance analysis (ANOVA) and Tukey's test, and $P<0.05$ was considered to be statistically significant. The data were interpreted using SPSS software version 16 .

\section{Results and discussion}

\section{Biosynthesis of $\mathrm{ZnONPS}$}

Zinc acetate dihydrate was used to synthesize $\mathrm{ZnONPs}$. The change in the color of acetate after the addition of the extract was the first step indetecting the formation of NPs. During the synthesis of zinc NPs using the $F$. parviflora extract, a clear change in the color of the mixture from dark brown to light brown indicated the production of $\mathrm{ZnONPs}$ (Fig. 1). 


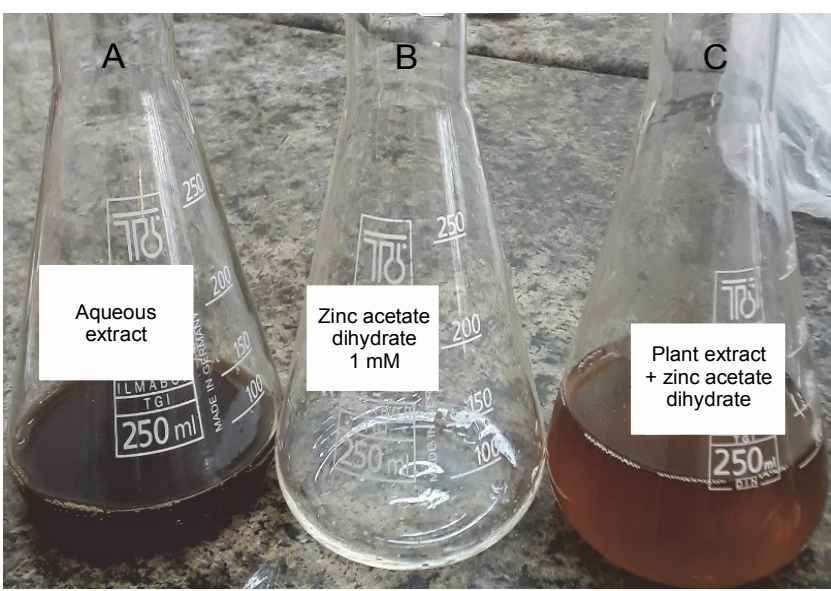

Fig. 1. Visual observation of $\mathrm{ZnONPs} \mathrm{A)} \mathrm{aqueous} \mathrm{extract} \mathrm{of} F u$ maria parviflora, B) zinc acetate dehydrate, C) plant extract $+\mathrm{ZnONPs}$

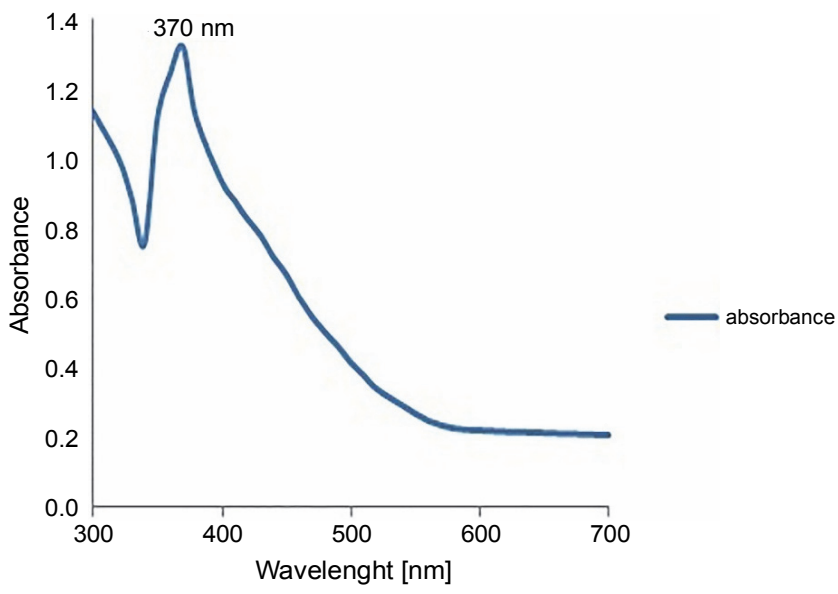

Fig. 2. UV-VIS spectrum ZnONPs synthesized by Fumaria parviflora extract

To further confirm the synthesis of zinc NPs, the absorption spectrum of the sample in the UV-VIS spectra was measured. The sample had a sharp absorbance peak at $370 \mathrm{~nm}$, which is in agreement with previous reports (Elumalai and Velmurugan, 2015; Zare et al., 2017), and conforms with the range of light absorption of $\mathrm{ZnONPs}$ (360-380 nm) (Nagarajan et al., 2013; Umar et al., 2019) - Figure 2.

\section{$X R D$ analysis}

$\mathrm{XRD}$ is known as a "fingerprint technique" as it provides a unique characteristic X-ray diffraction pattern of each crystalline solid for its identification. XRD can be used to determine the structure of crystalline solids, i.e., how the atoms are packed together in the crystalline state, what are the interatomic distanceand angle, etc.

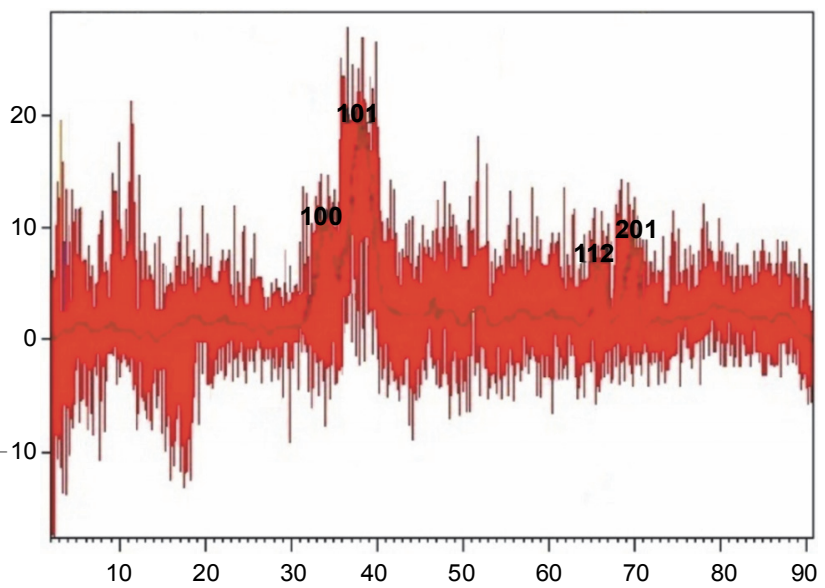

Fig. 3. XRD spectrum of ZnONPs synthesized by Fumaria parviflora extract

(Khaing et al., 2018). The XRD pattern of the synthesized $\mathrm{ZnONPs}$ clearly indicated the crystalline structure of the synthesized NPs (Fig. 3). The XRD pattern showed four distinct diffraction peaks at 31.86, 36.22, 67.71 , and 68.83 degrees. These peaks wereindexed as (100), (101), (112), and (201) diffraction lattice planes, respectively, which confirmed the hexagonal wurtzite structure of the synthesized NPs; this finding is in agreement with Joint Committee on Powder Diffraction Standards (JCPDS) card no. 36-1451 (Talam et al., 2012; Ghamsari et al., 2019; Alamdari et al., 2020). The average size of $\mathrm{ZnONPs}$ was calculated from the highest intense peak (101) using the Debye-Scherer equation:

$$
D=0.89 \lambda /(\beta \cos \theta)
$$

where $D$ is the crystallite size of $\mathrm{ZnONPs}, \lambda$ is the wavelength, $\beta$ is the full width at half maximum of the diffraction peak and $\theta$ is the Bragg angle in degrees (Safawo et al., 2018). The average crystallite size calculated for the synthesized $\mathrm{ZnONPs}$ was $16 \mathrm{~nm}$. The particle size of the synthesized $\mathrm{ZnONPs}$ was in close agreement with previous findings (Talam et al., 2012; Alwan et al., 2015).

\section{SEM analysis}

The morphology and size of the synthesized ZnONPs were determined by SEM analyses (Fig. 4).The ZnONPs were spherical in shape with particle size ranging from 42 to $60 \mathrm{~nm}$, clustered together, and with rough surface of the aggregates. The obtained results were almost identical to the findings of Gul et al. (2019). These 


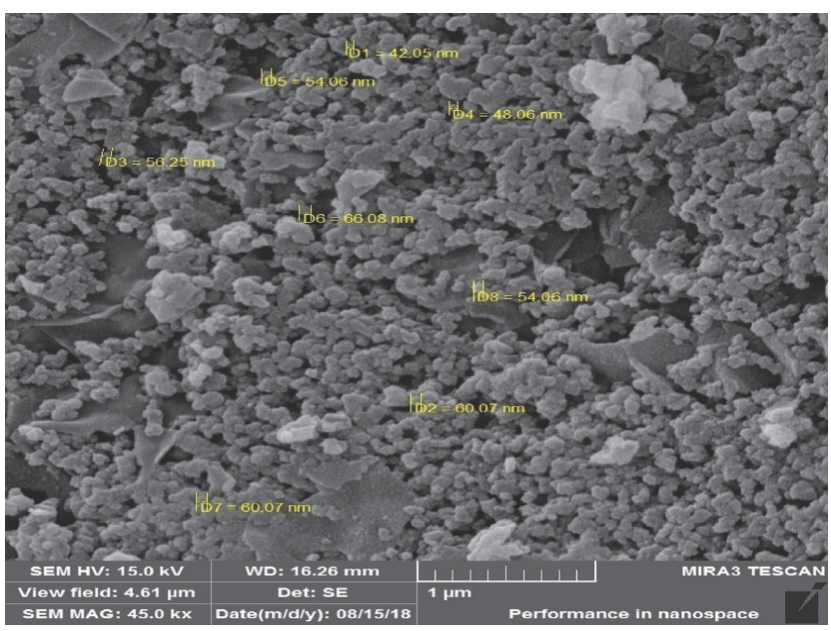

Fig. 4. SEM image of ZnONPs synthesized by Fumaria parviflora extract

authors synthesized $\mathrm{ZnONPs}$ by using an aqueous extract of Viola and observed that the NPs were spherical in shape with an average size of $42-60 \mathrm{~nm}$. In another study, the ZnONPs synthesized using an orange fruit peel extract were spherical in shape with an average size of 35-60 nm (Thi et al., 2020). Similar morphologies were also reported in previous studies. Sphericalshaped NPs were reported for those obtainedusing aqueous leaf extracts of three plants, i.e., Aloe vera, Azadirachta indica (L.), Abutilon indicum, and Clerodendrum inerme (Sangeetha et al., 2011; Elumalai and Velmurugan, 2015; Khan et al., 2018).

\section{Antioxidant activity of $\mathrm{ZnONPS}$}

ZnONPs showed effective inhibition activity in the DPPH scavenging assay as compared to the standard ascorbic acid (Fig. 5). The significant antioxidant potential of $\mathrm{ZnONPs}$ wasdue to the hydrogen-donating ability of the active phytochemicals of $F$. parviflora, such as flavonoids, glycosides, tannins, saponins, steroids, phenols, and alkaloids that are capped over ZnONPs (Parashant et al., 2015). The DPPH activity of the ZnONPs was found to increase in a dose-dependent manner. When ZnONPs were added to the DPPH solution, a color change occurred due to the scavenging of DPPH because of donation of a hydrogen atom to stabilize the DPPH molecule, which is responsible for the absorbance at $517 \mathrm{~nm}$ (Thomas et al., 2018). Previous studies support the antioxidant activity of $\mathrm{ZnONPs}$ (Das et al., 2013; Stan et al., 2016; Safawo et al., 2018). The DPPH values

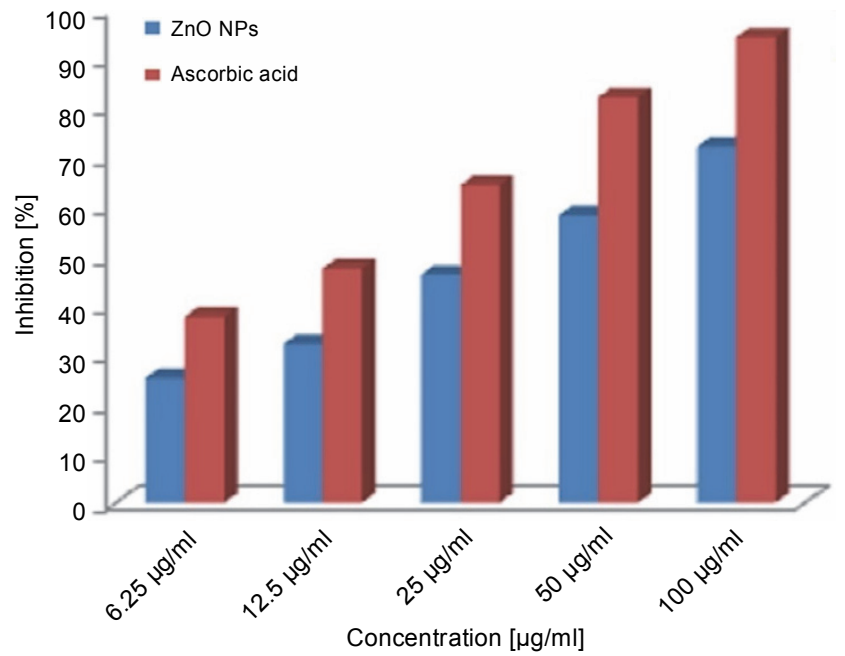

Fig. 5. Antioxidant activity of $\mathrm{ZnONPs}$ synthesized by plant extract in comparison with ascorbic acid

increased in a dose-dependent manner. The recorded value for the lowest concentration of the $\mathrm{ZnONPs}$ $(6.25 \mu \mathrm{g} / \mathrm{ml})$ was $25.25 \pm 0.04$, and this value increased to $72.12 \pm 0.12$ when the concentration increased to $100 \mu \mathrm{g} / \mathrm{ml}$. The percent inhibition of DPPH radicals by the $\mathrm{ZnONPs}$ was $72.12 \%$ at $1000 \mu \mathrm{g} / \mathrm{ml}$, whereas it was $94.25 \%$ for ascorbic acid (standard) at $1000 \mu \mathrm{g} / \mathrm{ml}$. The radical scavenging capacity of the synthesized $\mathrm{ZnONPs}$ was slightly lower than that of the standard ascorbic acid at all the tested concentrations of NPs (Fig. 5). The obtained results also revealed that the recorded $\mathrm{IC}_{50}(50 \%$ inhibition of free radicals) values of $\mathrm{ZnONPs}$ and ascorbic acid (usedas a positive control) for DPPH radical inhibition were 30.86 and $15.13 \mu \mathrm{g} / \mathrm{ml}$, respectively. This finding suggests that the synthesized ZnONPs showed good antioxidant activity as compared to ascorbic acid. Previously, ZnONPs synthesized by using an aqueous extract of Coccinia abyssinica exhibited the maximum DPPH scavenging activity of $60.12 \%$ at $100 \mu \mathrm{g} / \mathrm{ml}$ and an $\mathrm{IC}_{50}$ value of $127.64 \mu \mathrm{g} / \mathrm{ml}$ (Safawo et al., 2018).

\section{Antimicrobial activity of $\mathrm{ZnONPS}$}

\section{Disc diffusion method}

The antibacterial activity of the green synthesized $\mathrm{ZnONPs}$ in comparison with vancomycin and amikacin standards was investigated at various concentrations $(25,50$, and $100 \mu \mathrm{g} / \mathrm{ml})$ against $S$. aureus and $E$. coli by using the disc diffusion method. The results are shown 


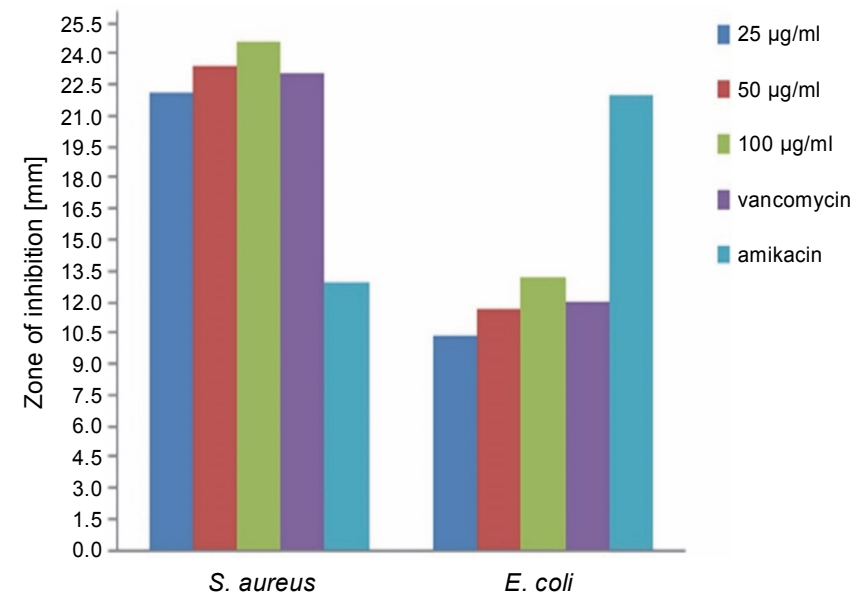

Fig. 6. Antibacterial activity of $\mathrm{ZnONPs}$ in comparison with standards antibiotic

Table 1. Bacterial growth inhibition of $\mathrm{ZnONPs}$ based on disc diffusion method

\begin{tabular}{c|c|c}
\hline \multicolumn{2}{c|}{ Zone of inhibition $[\mathrm{mm}]$} & \multirow{2}{*}{$\begin{array}{c}\text { ZnONPs } \\
{[\mu \mathrm{g} / \mathrm{ml}]}\end{array}$} \\
\cline { 1 - 2 } E. coli & S. aureus & 25 \\
\hline $10.4 \pm 0.50$ & $22.1 \pm 0.41$ & 50 \\
\hline $11.7 \pm 0.25$ & $23.4 \pm 0.16$ & 100 \\
\hline $13.2 \pm 0.81$ & $24.6 \pm 0.72$ & vancomycin \\
\hline $12.0 \pm 0.41$ & $23 \pm 0.51$ & amikacin \\
\hline $22.0 \pm 0.60$ & $13 \pm 0.40$ & mean $\pm \mathrm{SD}, n=3$
\end{tabular}

in Figure 6 and Table 1. It was observed that the synthesized $\mathrm{ZnONPs}$ showed anantibacterial effect against $S$. aureus and E. coli at all the tested concentrations; the synthesized NPs also exhibited enhanced antibacterial activity against $S$. aureus as compared to the synthetic antibiotics vancomycin and amikacin. The antibacterial activity increased with an increase in the concentration of $\mathrm{ZnONPs}$. This result was consistent with the findings of Sangeetha et al. (2011), where it was found that with the increase in the concentration of $\mathrm{ZnO}$ nanoparticles, the growth inhibition also consistently increased. The biosynthesized ZnONPs (at $100 \mu \mathrm{g} / \mathrm{ml}$ concentration) showed the highest zone of inhibition $(24.6 \mathrm{~mm})$ against gram-positive $S$. aureus and the lowest zone of inhibition $(13.2 \mathrm{~mm})$ against gram-negative E. coli $(P<0.05)$, which implies that gram-negative bacteria might show higher resistance to ZnONPs. Our findings were in agreement with other similar reports where the antimicrobial properties of $\mathrm{ZnONPs}$ syn- thesized using different plant extracts were studied. Ambika and Sundrarajan (2015) reported that $\mathrm{ZnONPs}$ synthesized using Pelargonium zonale leaf extract had the strongest antibacterial activity against $S$. aureus $(20 \mathrm{~mm})$ than against $E$. coli $(14 \mathrm{~mm})$. On the other hand, Elumalai and Velmurugan (2015) showed a potent antibacterial activity of $\mathrm{ZnONPs}$ synthesized using leaf extract of Azadirachta indica (L.), withthe strongest antibacterial activity against $S$. aureus $(19 \mathrm{~mm})$ than against E. coli $(17 \mathrm{~mm})$. Sonia et al. (2017) showed strong antimicrobial potential of $\mathrm{ZnONPs}$ against both gram-positive and gram-negative bacteria. Some previous studies also showed antibacterial activity of $\mathrm{ZnONPs}$ synthesized using different plant extracts against grampositive and gram-negative bacteria (Raghupathi et al., 2011; Sharma et al., 2016; Jahanpanahiand and Ali Mohamadi, 2016; Vahidi et al., 2019).

\section{Microdilution method}

The MIC and MBC values of $\mathrm{ZnONPs}$ obtained for the pathogenic bacterial species are reported in Table 2 . According to these results, the lowest MIC and MBC values of $\mathrm{ZnONPs}$ against $S$. aureus were 1.56 and $3.12 \mu \mathrm{g} / \mathrm{ml}$, respectively, and the lowest MIC and MBC values against $E$. coli were 6.25 and $12.5 \mu \mathrm{g} / \mathrm{ml}$, respectively. The results of MIC and MBC assays were similar to those obtained for the disc diffusion assay. Accordingly, these results indicate that the antibacterial activity of $\mathrm{ZnONPs}$ was higher for gram-positive bacteria than for gram-negative bacteria. Our result is also consistent with previous studies. Safawo et al. (2018) reported that $S$. aureus exhibited higher sensitivity toward $\mathrm{ZnONPs}$ with $21 \mathrm{~mm}$ zone of inhibition. The MIC value of $Z \mathrm{nONPs}$ against $S$. aureus was $1.25 \mu \mathrm{g} / \mathrm{ml}$. This could be because gram-positive bacteria lack the outer membrane and have a thick peptidoglycan layer, which makes them sensitive to $\mathrm{ZnONPs}$, unlike gram-negative bacteria that have an outer membrane with a thin peptidoglycan layer rich in lipopolysaccharides, lipids, and lipoproteins that are quite resistant to ZnONPs (Ahmed et al., 2017).

The antimicrobial activities of $\mathrm{ZnONPs}$ toward bacteria depend on particle size, powder concentration, morphology, specific surface area, release of reactive oxygen species (ROS), and zinc ions. Generated ROS species, hydrogen peroxide $\left(\mathrm{H}_{2} \mathrm{O}_{2}\right), \mathrm{OH}^{-}$(hydroxyl radicals), $\mathrm{O}_{2}^{-2}$ (peroxide), and zinc ions from $\mathrm{ZnONPs}$ bind to the negative surface of the cell membrane, leading to dis- 
Table 2. MIC and MBC of ZnONPs

\begin{tabular}{c|c|c}
\hline Microbial strain & $\begin{array}{c}\mathrm{MIC} \\
{[\mu \mathrm{g} / \mathrm{ml}]}\end{array}$ & $\begin{array}{c}\mathrm{MBC} \\
{[\mu \mathrm{g} / \mathrm{ml}]}\end{array}$ \\
\hline S. aureus & 1.56 & 3.12 \\
\hline E. coli & 6.25 & 12.5 \\
\hline
\end{tabular}

ruption of the cells followed by leakage of inner cellular material that causes cell death (Sangeetha et al., 2011; Elumalai and Velmurugan, 2015). The increase in the concentration of $\mathrm{ZnONPs}(25,50$, and $100 \mu \mathrm{g} / \mathrm{ml})$ and the observed increase in antimicrobial activities is due to the increase in $\mathrm{H}_{2} \mathrm{O}_{2}$ concentration from the surface of $\mathrm{ZnO}$ (Sangeetha et al., 2011).

\section{Conclusions}

Our study results showed that green synthesis of $\mathrm{ZnONPs}$ was conducted successfully from the aqueous extract of $F$. parviflora. UV-Vis analysis confirmed the synthesis of $\mathrm{ZnONPs}$, and SEM images reported individual particle size in the range of $42-64 \mathrm{~nm}$. Hexagonal structure of the synthesized $\mathrm{ZnONPs}$ was confirmed by X-ray diffraction analysis. The DPPH assay indicated that the synthesized $\mathrm{ZnONPs}$ have antioxidant activity with $\mathrm{IC}_{50}$ value of $30.86 \mu \mathrm{g} / \mathrm{ml}$. The synthesized ZnONPs also showed better antibacterial activity against gram-positive bacteria than against gram-negative bacteria.

\section{Acknowledgments}

The authors acknowledge the Centre of the Laboratory in Lorestan University for providing support in conducting X-ray diffraction and SEM analyses. This work was supported by the Deputy of Research and Technology, Islamic Azad University, Khorramabad Branch, Iran.

\section{References}

Agarwal H., Kumar S.V., Rajeshkumar S. (2017) A review on green synthesis of zinc oxide nanoparticles - an ecofriendly approach. Res. Eff. Tech. 3: 406-413.

Ahmad N., Sharma S., Alam M.K., Singh V., Shamsi S., Mehta B., Fatma A. (2010) Rapid synthesis of silver nanoparticles using dried medicinal plant of basil. Coll. Surf. B. 81: 81-86.

Ahmed S., Chaudhry S.A., Ikram S. (2017) A review on biogenic synthesis of $\mathrm{ZnO}$ nanoparticles using plant extracts and microbes: a prospect towards green chemistry. J. Photochem. Photobiol. B. 166: 272-284.

Alamdari S., Sasani Ghamsari M., Lee C., Han W., Park H.H., Jafar Tafreshi M., Afarideh H., Majles Ara M.H. (2020)
Rreparation and characterization of zinc oxide nanoparticles using leaf extract of Sambucus ebulus. Appl. Sci. 10: 3620 .

Alqasoumi S.A., Al-Dosari M.S., AlSheikh A.M., Abdel-Kader M.S. (2009) Evaluation of the hepatoprotective effect of Fumaria parviflora and Momordica balsamina from Saudi folk medicine against experimentally induced liver injury in rats. Res. J. Medicinal. Plant. 3(1): 9-15.

Al-Shaibani I.R.M., Phulan M.S., Shiekh M. (2009) Fumaria parviflora [Fumariaceae] against gastrointestinal nematodes of sheep. Int. J. Agric. Biol. 11: 431-436.

Alwan R.M., Kadhim Q.A., Sahan K.M., Ali R.A., Mahdi R.J., Kassim N.A., Jassim A.N. (2015) Synthesis of zinc oxide nanoparticles via sol-gel route and their characterization. J. Nanosci. Nanotechnol. 5(1): 1-6.

Ambika S., Sundrarjan M. (2015) Plant-extract mediated synthesis of $\mathrm{ZnO}$ nanoparticles using Pongamia pinnata and their activity against pathogenic bacteria. Adv Powder Technol. 26(5): 1294-1299.

Andeani J.K., Kazemi H., Mohsenzadeh S., Safavi A. (2011) Biosynthesis of gold nanoparticles using dried flowers extract of Achillea wilhelmsii plant. Dig. J. Nanomater. Bios. 6: 1011-1017.

Anitha R., Ramesh K.V., Ravishankar T.N., Sudheer Kumar K.H., Ramakrishnappa T. (2018) Cytotoxicity, antibacterial and antifungal activities of $\mathrm{ZnO}$ nanoparticles prepared by the Artocarpus gomezianus fruit mediated facile green combustion method. J. Sci. Adv. Mater. Dev. 3(4): 440-451.

Ankamwar B., Chaudhary M., Sastry M. (2005) Gold nanotriangles biologically synthesized using tamarind leaf extract and potential application in vapor sensing. Synthesis and reactivity in inorganic. Inorg. Nano-Met. Chem. 35(1): 19-26.

Azimzadeh M. (2009) Genetic assessment of Iranian Bunium Persicum Boiss using ITS. [MSc thesis]. Tehran. University of Tehran, Abourayhan campus: 81.

Azizi M.B., Ahmad M., Namvar F., Mohamad R. (2014) Green biosynthesis and characterization of zinc oxide nanoparticles using brownmarine macroalga Sargassum muticum aqueous extract. Mater. Lett. 116: 275-277.

Bekkari R., laanab L., Boyer D., Mahiou R., Jaber B. (2017) Influence of the sol gel synthesis parameters on the photoluminescence properties of $\mathrm{ZnO}$ nanoparticles. Mater. Sci. Semicond. Process. 71: 181-187.

Bhakya S., Muthukrishnan S., Sukumaran M., Muthukumar M. (2016) Biogenic synthesis of silver nanoparticles and their antioxidant and antibacterial activity. Appl. Nanosci. 6(5): 755-766.

Boroumand Moghaddam A., Mona Moniri M., Azizi S., Abdul Rahim R., Ariff A.B., Saad W.Z, Namvar F., Navaderi M., Mohamad R. (2017) Biosynthesis of $Z n O$ nanoparticles by a new Pichia kudriavzevii yeast strain and evaluation of their antimicrobial and antioxidant activities. Molecules 22(6): 872.

Brintha S.R., Ajitha M. (2015) Synthesis and characterization of $\mathrm{ZnO}$ nanoparticles via aqueous solution, sol-gel and hydrothermal methods. IOSR J. Appl. Chem. 8: 66-72. 
Das D., Nath B.C., Phukon P., Dolui S.K. (2013) Synthesis of $\mathrm{ZnO}$ nanoparticles and evaluation of antioxidant and cytotoxic activity. Coll. Surf. B. Biointerf. 111: 556-560.

Dwivedi A.D., Gopal K. (2010) Biosynthesis of silver and gold nanoparticles using Chenopodium album leaf extract. Colloids Surf. A Physicochem. Eng. Asp. 369(1-3): 27-33.

El-Gharbawy R.M., Emara A.M., Abu-Risha S.E. (2016) Zinc oxide nanoparticles and a standard antidiabetic drug restore the function and structure of beta cells in Type-2 diabetes. Biomed Pharmacother. 84: 810-820.

Elumalai K., Velmurugan S. (2015) Green synthesis, characterization and antimicrobial activities of zinc oxide nanoparticles from the leaf extract of Azadirachtaindica (L.). Appl. Surf. Sci. 345: 329-336.

Fakhari S., Jamzad M., KabiriFard H. (2019) Green synthesis of zinc oxide nanoparticles: a comparison. Green. Chem. Lett. Rev. 12(1): 19-24.

Fathiazad F., Hamedeyazdan S., Khosropanah M.K., Khaki A. (2013) Hypoglycemic activity of Fumariaparviflorain streptozotocin-induced diabetic rats. Adv. Pharm. Bull. 3(1): 207-210.

Ghaffarian H.R., Saiedi M., Sayyadnejad M.A. (2011) Synthesis of $\mathrm{ZnO}$ nanoparticles by spray pyrolysis method. Iran. J. Chem. Chem. Eng. 30(1): 1-6.

Guan Y.F., Pedraza A.J. (2008) Synthesis and alignment of $Z n$ and $\mathrm{ZnO}$ nanoparticles by laser-assisted chemical vapor deposition. Nanotechnology 19(4): 045609.

Gul S., Hashim Y.Z.H., Puad N.L.I., Samsudin N. (2019) Fabrication and characterization of plant mediated green zinc nanoparticles for antileishmanial properties. J. Recent Technol. Eng. 8(9): 5743-5749.

Gunalan S., Sivaraj R., Rajendran V. (2012) Green synthesized $\mathrm{ZnO}$ nanoparticles againstbacterial and fungal pathogens. Prog. Nat. Sci-Mater. 22(6): 693-700.

Ghamsari M.S., Alamdari S., Razzaghi D., Pirlar M.A. (2019) $\mathrm{ZnO}$ nanocrystals with narrow-band blue emission. J. Lumin. 205: 508-518.

Huang J., Li Q., Sun D., Lu Y., Su Y., Yang X., He N. (2007) Biosynthesis of silver and gold nanoparticles by novel sundried Cinnamomumcamphora leaf. Nanotechnology 18(10): 105104.

Jahanpanahiand M., Ali Mohamadi S. (2016) Antimicrobial effect of nanofluid including Zinc oxide ( $\mathrm{ZnO}$ ) nanoparticles and Mentha pulegium essential oil. J. Appl. Biol. Biotechnol. 4(04): 085-089.

Jamdagni P., Khatri P., Rana J.S. (2016) Green synthesis of zinc oxide nanoparticles using flower extract of $N y c t a n t h e s$ arbor-tristis and their antifungal activity. J. King. Saud. Univ. Sci. 30(2): 168-175.

Jameel M., Ali A., Ali M. (2014) New phytoconstituents from the aerial parts of Fumaria parviflora Lam. J. Adv. Pharm. Technol. Res. 5(2): 64 .

Jiménez A.B.P., Aguilar C.A.H., Ramos J.M.V., Thangarasu P. (2015) Synergistic antibacterial activity of nanohybrid materials $\mathrm{ZnO}-\mathrm{Ag}$ and $\mathrm{ZnO}-\mathrm{Au}$ : synthesis, characterization, and comparative analysis of undoped and doped $\mathrm{ZnO}$ nanoparticles. Aust. J. Chem. 68(2): 288-297.
Khaing M.M., Thu M.K., Kyaw T., Tin T., Lwin T. (2018) Green synthesis of zinc oxide nanoparticles using tropical plants and their characterizations. Int. J. Sci. Eng. Res. 9(8): 1627-1725.

Khan S.A., Noreen F., Kanwal S., Iqbal A., Hussain G. (2018) Green synthesis of $\mathrm{ZnO}$ and $\mathrm{Cu}$-doped $\mathrm{ZnO}$ nanoparticles from leaf extracts of Abutilon indicum, Clerodendrum infortunatum, Clerodendrum inerme and investigation of their biological and photocatalytic activities. Mater. Sci. Eng. C. 82: 46-59.

Kong Y.C., Yu D.P., Zhang B., Fang W., Feng S.Q. (2001) Ultraviolet-emitting $\mathrm{ZnO}$ nanowires synthesized by a physical vapor deposition approach. Appl. Phys. Lett. 78: 407-409.

Krol A., Pomastowski P., Rafinska K., Railean-Plugaru V., Buszewski B. (2017) Zinc oxide nanoparticles: synthesis, antiseptic activity and toxicity mechanism. Adv. Colloid Interface Sci. 249: 37-52.

Kundu D., Hazra C., Chatterjee A., Chaudhari A., Mishra S. (2014) Extracellular biosynthesis of zinc oxide nanoparticles using Rhodococcus pyridinivorans NT2: multifunctional textile finishing, biosafety evaluation and in vitro drug delivery in colon carcinoma. J. Photochem. Photobiol. B: Biol. 140: 194-204.

Nabipour F., Dousti B. (2018) Comparison of the antifungal effects of various extracts of Onosma chlorotricum on Candida albicans and Candida glaberata with two antibiotics fluconazole and nystatin. Yafte 20(1): 12-22.

Nagarajan S., Kuppusamy K.A. (2013) Extracellular synthesis of zinc oxide nanoparticle using Seaweeds of Gulf of Manner, India. J. Nano. Biotechnol. 11: 1-11.

Nam K.T., Kim D.W., Yoo P.J., Chiang C.Y., Meethong N., Hammond P.T., Ching M.Y., Belcher A.M. (2006) Virusenabled synthesis and assembly of nanowires for lithium ion battery electrodes. Science 312: 885-888.

Naveed A., Haq U., Nadhman A., Ullah I., Mustafa G., Yasinzai M., Khan I. (2017) Synthesis approaches of zinc oxide nanoparticles: the dilemma of ecotoxicity. J. Nanomater. 2017: 1-14.

Orhan I., Sener B., Choudhary M.I., Khalid A. (2004) Acetylcholinesterase and butyrylcholinesterase inhibitory activity of some Turkish medicinal plants. J. Ethnopharmacol. 91(1): 57-60.

Orhan I.E., Şener B., Musharraf S.G. (2012) Antioxidant and hepatoprotective activity appraisal of four selected $\mathrm{Fu}$ maria species and their total phenol and flavonoid quantities. Exp. Toxicol. 64(3): 205-209.

Parashant G.K., Prashant P.A., Utpal B., Manoj G., Nagabhushana B.M., Ananda S., Krishnaiah G.M., Sathyananda H.M. (2015) In vitro antibacterial and cytotoxicity studies of ZnOnanopowders prepared by combustion assisted facile green synthesis. Karbala. Int. J. Mod. Sci. 1(2): 67-77.

Raghupathi K.R., Koodali R.T., Manna A.C. (2011) Size-dependent bacterial growth inhibition and mechanism of antibacterial activity of zinc oxide nanoparticles. Langmuir 27(7): 4020-4028. 
Ramesh P., Rajendran A., Meenakshisundaram M. (2014) Green syntheis of zinc oxide nanoparticles using flower extract Cassia auriculata. J. Nanosci. Nanotechnol. 2(1): 41-45.

Rehman N.U., Mehmood M.H., Al-Rehaily A.J., Mothana R.A., Gilani A.H. (2012) Species and tissue-specificity of prokinetic, laxative and spasmodic effectsof Fumaria parviflora. BMC Compl. Altern. Med. 12: 16.

Rizvi W., Fayazuddin M., Singh O., Syed S.N., Moin S., Akhtar K., Kumar A. (2017) Anti-inflammatory effect of Fumaria parviflora leaves based on TNF- $\alpha, I L-1, I L-6$ and antioxidant potential. Avicenna. J. Phytomed. 7(1): 37-45.

Safawo T., Sandeep B., Pola S., Tadesse A. (2018) Synthesis and characterization of zinc oxide nanoparticles using tuber extract of anchote (Coccinia abyssinica (Lam.) Cong.) for antimicrobial and antioxidant activity assessment. OpenNano 3: 56-63.

Salem W.R., Leitner D.G., Zingl F., Schratter G., Prassl R., Goessler W., Reidl J., Schild S. (2015) Antibacterial activity of silver and zinc nanoparticles against Vibrio cholerae and enterotoxic Escherichia coli. Int. J. Med. Microbiol. Suppl. 305(1): 86-95.

Sangeetha G., Rajeshwari S., Venckatesh R. (2011) Green synthesis of zinc oxide nanoparticles by aloe barbadensis miller leaf extract: structure and optical properties. Mater. Res. Bull. 46: 2560-2566.

Sharma N., Jandaik S., Kumar S., Chitkara M., Sandhu I.S. (2016) Synthesis, characterisation and antimicrobial activity of manganese-andiron-doped zinc oxide nanoparticles. J. Exp. Nanosci . 11(1): 54-71.

Shoushtari M.Z., Parhoodeh S., Farbod M. (2008) Fabrication and characterization of zinc oxide nanoparticles by DCArc Plasma. J. Phys. Conf. Ser., 100: 052017.

Stan M., Popa A., Toloman D., Silipas T.D., Vodnar D.C. (2016) Antibacterial and antioxidant activities of $\mathrm{ZnO}$ nanoparticles synthesized using extracts of Allium sativum, Rosmarinus officinalis and Ocimum basilicum. Acta Metal. Sinica 29: 228-236.

Selvakumar J.N., Chandrasekaran S.D., Vaithilingam M. (2015) Bio prospecting of marine-derived Streptomyces spectabilisVITJS10 and exploring its cytotoxicity against human liver cancer cell lines. Phcog. Mag. 11: 469-473.

Sonia S., Kumari H.L., Ruckmani K., Sivakumar M. (2017) Antimicrobial and antioxidant potentials of biosynthesized colloidal zincoxide nanoparticles for afortified cold cream formulation: a potent nanocosmeceutical application. Mater Sci. Eng. C Mater. Biol. Appl. 79: 581-589.

Soren S., Kumarb S., Mishraa S., Jenac P.K., Vermad S.K., Parhia P. (2018) Evaluation of antibacterial and antioxidant potential of the zinc oxidenanoparticles synthesized by aqueous and polyol method. Microb. Pathog. 19: 145-151.

Talam S., Karumuri S.R., Gunnam N. (2012) Synthesis, characterization, and spectroscopic properties of $\mathrm{ZnO}$ nanoparticles. ISRN Nanotech. 2012: 1-6.

Thi U.D.T., Nguyaen T.T., Thi Y.D., Thi K.H.T., Phan B.T., Pham K.N. (2020) Green synthesis of $\mathrm{ZnO}$ nanoparticles using orangefruit peel extract for antibacterial activities. RSC Adv. 10: 23899-23907.

Thomas B., Arul Prasad A., Mary Vithiya S. (2018) Evaluation of antioxidant, antibacterial and photo catalytic effect of silver nanoparticles from methanolic extract of Coleus vettiveroids - an endemic species. J. Nanostruct. 8(2): 179-190.

Umar H., Kavaz D., Rizaner N. (2019) Biosynthesis of zinc oxide nanoparticles using Albizialebbeck stem bark, and evaluation of its antimicrobial, antioxidant, and cytotoxic activities on human breast cancer cell lines. Int. J. Nanomedicine. 14: 87-100.

Uzzaman S., Mashraia A., Khanama H., Aljawfi R.N. (2017) Biological synthesis of $\mathrm{ZnO}$ nanoparticles using $C$. albicans and studying their catalytic performance in the synthesis of steroidalpyrazolines. Arab. J. Chem. 10: 1530-1536.

Vahidi A., Vaghari H., Najian Y., Najian M.J., Jafarizadeh H. (2019) Evaluation of three different green fabrication methods for the synthesis of crystalline $\mathrm{ZnO}$ nanoparticles using Pelargonium zonale leaf extract. Green. Process. Synth. 8: 302-308.

Wang Y., He X., Wang K., Zhang X., Tan W. (2009) Barbated Skull cup herb extract-mediated biosynthesis of gold nanoparticles and its primary application in electrochemistry. Coll. Surf. B: Biointerfaces 73(1): 75-79.

Zare E., Pourseyedi S., Khatami M., Darezereshki E. (2017) Simple biosynthesis of zinc oxide nanoparticles using nature's source, and it's in vitro bioactivity. J. Mol. Struct. 1146: 96-103. 